Indonesian Journal of Biotechnology, December, 2011

Vol. 16, No. 2, pp.126-131

\title{
T-786c Polymorphism in nitric oxide synthase 3 gene and Nitrit Oxide Level of Diabetic Retinopathy in Javanese Population
}

\author{
Putri Widelia Welkriana ${ }^{1}$, Sunarti ${ }^{2}$, and Pramudji Hastuti ${ }^{2}$
}

\author{
${ }^{1}$ Postgraduated Program of Basic and Biomedical Science, Faculty of Medicine, Universitas Gadjah \\ Mada, Yogyakarta, Indonesia \\ ${ }^{2}$ Department of Biochemistry, Faculty of Medicine, Universitas Gadjah Mada, Yogyakarta, Indonesia
}

\begin{abstract}
Complication of retinopathy in type $2 \mathrm{DM}$ is caused of lower level of NO. Nitric oxide level is synthesized from L-arginin in reaction that catalyze Nitric oxide synthase (NOS) 3. The T-786C mutation in NOS 3 gene decreases the expression of nitric oxide synthase (NOS) 3 so decreases NO synthesis. To investigate the association between T-786C polymorphism in NOS 3 gene with NO level of diabetic retinopathy patients. This study was a case control study, consist of 40 patient of type 2 diabetic with DR (case group) and 40 patient of type 2 diabetic without DR (control group) of Javanese ethnic. The genotyping of T-786C polymorphism was performed by PCR-RLFP. Level of NO was measured by spectrophotometry. Chi square test and odd ratio were used to analyze the association of the T-786C polymorphism in NOS 3 gene with DR. Differences of NO level between TT and TC genotypes were analyzed using independent $t$ test. The distribution of T-786C polymorphism in NOS 3 gene of DR subjects showed that frequency of TT genotype was $22.5 \%$ and TC genotype was $77.5 \%$. Non DR subjects showed the frequency of TT genotype was $50 \%$ and TC genotype was $50 \%$, ( $p=$ 0.011). Frequency of $\mathrm{T}$ allele in DR group was $61.25 \%$ and $\mathrm{C}$ allele was $38.75 \%$, and frequency of $\mathrm{T}$ allele in non DR group was $75 \%$ and C allele was $25 \%$, ( $p=0.62$ ). Odd ratio of TC genotype was $3.444(\mathrm{CI} ; 95 \%: 0.964-3.735)$ and C allele was 1.898 (CI; 95\% : 1.310-9.058). The NO level of TC genotype was $1.43 \pm 0.126$ and TT genotype was $11.27 \pm 5.87(p=0.000)$. Level of NO between RD and non RD showed not different significantly $(p=0.160)$ for retinopathy. The T-786C polymorphism of NOS 3 gene is risk factor for retinopathy in type 2 Diabetes Mellitus. Individual with TC genotype of NOS 3 gene has lower level of NO than TT genotype.
\end{abstract}

Keywords : Diabetic Retinopathy, Polymorphism, Nitric Oxide, Nitric Oxide Synthase.

\section{Introduction}

Diabetes Mellitus (DM) is a metabolic disease characterized by hyperglycemia. It is caused by defect on insulin secretion, insulin activity, or both (Gustaviani, 2006). Based on WHO database, the number of DM patients in the world has reached 171 million people (2.8\% of world population). In 2007, the prevalence of DM in Indonesia was approximately 5.7\% (Depkes RI, 2008).

\footnotetext{
*Corresponding Author:

Sunarti

Department of Biochemistry, Faculty of Medicine, Universitas Gadjah Mada, Yogyakarta, Indonesia, Email : nartyr-r@ugm.ac.id
}

In Yogyakarta, the DM patients has reached approximately 150/10.000 citizens, therefore its prevalence is $1.6 \%$ (Depkes RI, 2008). The complications of DM is retinopathy, nephropathy, and peripheral neuropathy. Diabetic Retinopathy (DR) is a microvascular complication which causes blindness (Gustaviani, 2006). The prevalence of DR in the world is $40 \%$, in Indonesia is about $40-$ $50 \%$ (Masduki et al., 2008). In Yogyakarta, the prevalence of DR in rural area is $8.7 \%$, while in suburban is 7.7\% (Gustaviani, 2006).

Retinal defect caused by hyperglycemia involves some pathways, such as nonenzymatic glycation, protein kinase $\mathrm{C}$ activation, increase of oxidative stress, polyol 
pathway, and decrease of NO. Chronic hyperglycemia increases free radicals, especially reactive oxygen species, in all of tissues causes oxidative stress. Oxidative stress cause change of the structural and functional retinal microvascular (Miyamoto et al., 2000) that is thickening of basal membrane and microvascular, loses the capillary form. Furthermore, structural changes may alter the function of pericyte cells and endothelial cells, such as decrease of blood stream, loss of intercellular junction, and increase of vessel permeability. The contractility of pericytes of retinal capillary is inhibited by high concentration of glucose. It is the early step of DR pathogenesis (Gillies and Su, 1993).

Several studies reported that several genes influence the development of DR. One of those gene is endothelial nitric oxide synthase (eNOS) or NOS 3 gene. NOS 3 gene is located in chromosome 7 (7q36). This gene encodes NOS 3 which catalyzes the formation of NO by the conversion of L-arginin to L-citrullin (Mayer and Hemes, 1997). Ezzidi et al., 2008 investigated T-786C polymorphism in NOS 3 gene that located in $-786 \mathrm{bp}$ upstream from NOS 3 gene. This polymorphism causes the conversion of timine to cytocine which leads to the decrease of NO synthesis. Low level of NO causes vasoconstriction, platelet aggregation, and angiogenesis.

The objective of this study was to give description about the relationship of T-786C polymorphism in NOS 3 gene as risk factor for DR in type 2 DM patients of Dr. Sardjito Hospital, Yogyakarta and level of NO.

\section{Materials and Methods}

This research was a case-control study with 40 subjects of type $2 \mathrm{DM}$ patients with DR as the case group and 40 subjects of type 2 DM patients without DR as the control group. The patients were the outpatients of Dr. Sardjito Hospital and they are all Javanese. The inclusion criteria of the research subject were aged 35-65 years, have been diagnosed as type $2 \mathrm{DM}$ patient minimally for 5 years, body mass index $\leq 25 \mathrm{~kg} / \mathrm{m}$ (WHO, 2006;
Supariasa et al., 2001), did not suffer from dyslipidemia, systolic blood pressure $<180$ $\mathrm{mmHg}$ and diastolic blood pressure $<120$ $\mathrm{mmHg}$ (JNC 7, 2003), did not have any eye disease. Informed consent was obtained from each subject.

Diagnosis of DM was established when the level of fasting plasma glucose $\geq 120 \mathrm{mg} /$ $\mathrm{dL}$ and 2-h plasma oral glucose tolerant $\geq$ $200 \mathrm{mg} / \mathrm{dL}$ (American Diabetes Association, 2010). The criterion of retinopathy was based on the photofundus examination that showed one of retinopathy symptoms, such as microaneurism, hemorrhage, exudates, or/and neovascularization.

The data obtained from the subjects were age, sex, course of DM, BMI, and blood pressure. NO level was measured using spectrophotometry with Griess reaction. The measurements of GDP and G2PP levels used GOD-PAP, while triglyceride, HDL, and LDL HDL, and LDL levels were measured using CHOD-PAP levels were measured using CHOD- PAP. The data was analyzed with independent $t$ test.

\section{Genotyping of NOS 3 gene polymorphism}

The T-786C polymorphism in NOS 3 gene was determined with PCR-RLFP method. The PCR conditions were $94^{\circ} \mathrm{C}$ for $5 \mathrm{~s}$; followed by 40 cycles of $94^{\circ} \mathrm{C}$ for $1 \mathrm{~min}$, $61^{\circ} \mathrm{C}$ for $1 \mathrm{~min}, 72^{\circ} \mathrm{C}$ for $1 \mathrm{~min}$; and final extension at $72^{\circ} \mathrm{C}$ for $5 \mathrm{~min}$. The primers used in this study were 5'-TGG AGA GTG CTG GTG TAC CCC A-3' (forward primer) and 5'-GCC TCC ACC CCC ACC CTG TC$3^{\prime}$ (reverse primer). From this amplification, PCR product of $180 \mathrm{bp}$ was expected (Ezzidi et al., 2008).

The enzyme for restriction was MspI restriction enzyme (New England Biolabs). The result of digestion for $16 \mathrm{~h}$ was then electrophorized with $2 \%$ agarose gel and visualized with ethidium bromide under UV light. Two fragments; 140 and 40 bp; represented TT genotype. Four fragments; $140,90,50$, and $40 \mathrm{bp}$; represented TC genotype, while three fragments; 90, 50, 
and $40 \mathrm{bp}$; represented CC genotype. The difference of genotype and allele frequencies between case and control groups were analyzed by chi-square test. The Odd Ratio test was used to analyze the extent to which various genotypes and alleles of T-786C polymorphism in NOS 3 gene was associated with DR.

\section{Results}

A total of 80 Javanese that consisted of 40 type 2 DM patients with DR and 40 type 2 DM patients without DR, was enrolled in this study. The characteristics of the studied population were shown in Table 1. BMI of DR patients and non DR patients was significantly different, but the average value of both groups was in normal range (Table 1 ).

The result of genotype analysis of T-786C polymorphism in NOS 3 gene using PCR-RFLP is shown in Figure 1.

The genotype and allele distribution of T-786C polymorphism in NOS 3 gene is shown in Table 2 while the Hardy-Weinberg equilibrium is shown in (Table 3 ).

Table 1. Characteristics of the studied population

\begin{tabular}{lllll}
\hline \multicolumn{1}{c}{ Variables } & \multicolumn{1}{c}{$\begin{array}{c}\text { Diabetic } \\
\text { Retinopathy }\end{array}$} & \multicolumn{1}{c}{ Non DR } & $p$ & \multicolumn{1}{c}{$(95 \% \mathrm{CI})$} \\
\hline Number of subjects & 40 & 40 & & \\
Sex : male (\%) & $13(32.5 \%)$ & $12(30 \%)$ & - & \\
$\quad$ female (\%) & $27(67.5 \%)$ & $28(70 \%)$ & & \\
Age (year)\# & $55,58 \pm 7,91$ & $56,03 \pm 8,26$ & 0,797 & $54,01-57,59$ \\
BMI (kg/m²) & $21,93 \pm 2,83$ & $23,37 \pm 1,84$ & $0,018^{*}$ & $4,69-4,81$ \\
Systolic blood pressure(mmHg)\# & $124,25 \pm 11,07$ & $123,00 \pm 12,03$ & 0,648 & $2,08-2,9$ \\
Diastolic blood pressure(mmHg)\# & $79,50 \pm 9,04$ & $80,25 \pm 8,00$ & 0,809 & $1,01-1,89$ \\
GDP (mg/dL)\# & $167,18 \pm 69,83$ & $142,26 \pm 66,23$ & 0,062 & $11,58-12,94$ \\
Glucose 2 PP (mg/dL) & $232,41 \pm 76.13$ & $206.29 \pm 91.80$ & 0,362 & $0,04-0,08$ \\
Triglyceride (mg/dL)\# & $122,91 \pm 26,89$ & $137,02 \pm 33,12$ & 0,862 & $13,07-13,89$ \\
Total cholesterol (mg/dL) & $172.81 \pm 47,02$ & $171,02 \pm 26,65$ & 0,302 & $10,47-11,88$ \\
HDL (mg/dL) & $75,34 \pm 17,01$ & $72,19 \pm 12,95$ & 0,252 & $10,90-11,98$ \\
LDL (mg/dL)\# & $101,95 \pm 23,80$ & $101,41 \pm 19,30$ & 0,130 & $92,88-91,81$ \\
\hline
\end{tabular}

Note : \# calculated with Mann Whitney test

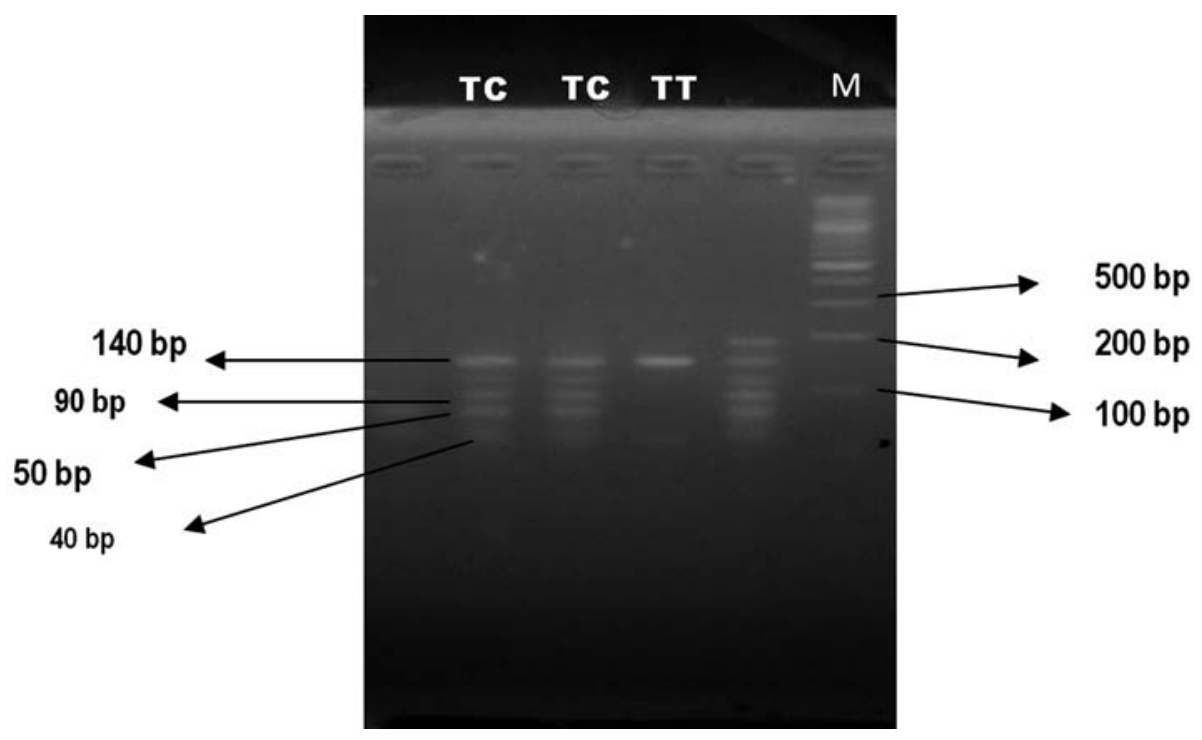

Figure 1. Genotype of TC and TT at -786 position NOS 3 gene 
Table 2. The genotype frequency of T-786C polymorphism in NOS 3 gene

\begin{tabular}{lcccc}
\hline Type 2 & \multicolumn{3}{c}{ Genotype } & $\mathrm{p}$ \\
\cline { 2 - 4 } DM & TT & TC & CC & $(\mathrm{CI}=95 \%)$ \\
\hline DR & $9(22.5 \%)$ & $31(77.5 \%)$ & $0(0 \%)$ & \multirow{2}{*}{0.011} \\
non DR & $20(50 \%)$ & $20(50 \%)$ & $0(0 \%)$ & \\
\hline
\end{tabular}

Pearson Chi-square analysis showed there was significantly different of genotype -786 NOS 3 gene in DR and non DR patients $(\mathrm{p}=0.011)$.

Table 3. The genotype frequency of T-786C polymorphism in NOS3 gene between the observed and the expected values (Hardy-Weinberg equilibrium)

\begin{tabular}{lccc}
\hline \multirow{2}{*}{ Genotype } & \multicolumn{2}{c}{ Result } & $\mathrm{p}$ \\
\cline { 2 - 3 } & $\begin{array}{c}\text { Observed } \\
\text { value }\end{array}$ & $\begin{array}{c}\text { Expected } \\
\text { value }\end{array}$ & $(95 \% \mathrm{CI})$ \\
\hline TT & 29 & 37 & \\
TC & 51 & 35 & 0.05 \\
CC & 0 & 8 & \\
\hline
\end{tabular}

With Hardy-Weinberg equilibrium, TT genotype was 37 , TC genotype was 35 , and CC genotype was 8 . With Pearson chi-square analysis showed a significant difference between the observed value and the expected (HardyWeinberg equilibrium) $(p=0.05)$ (Table 3$)$.

Table 4. The odds ratio of T-786C genotype and allele in NOS 3 gene

\begin{tabular}{|c|c|c|c|c|c|}
\hline \multirow{2}{*}{\multicolumn{2}{|c|}{ Variables }} & \multicolumn{2}{|c|}{ Type 2 DM } & \multirow[b]{2}{*}{ OR } & \multirow[b]{2}{*}{$95 \%$ CI } \\
\hline & & $\begin{array}{c}\mathrm{DR} \\
(\mathrm{n}=40)\end{array}$ & $\begin{array}{c}\text { non DR } \\
(\mathrm{n}=40)\end{array}$ & & \\
\hline \multirow[t]{2}{*}{ Genotype } & TC & 31 & 20 & 3.444 & $1.310-9.058$ \\
\hline & $\mathrm{TT}$ & 9 & 20 & & \\
\hline \multirow[t]{2}{*}{ Allele } & $C$ & 31 & 20 & 1.898 & 0.964-3.735 \\
\hline & $\mathrm{T}$ & 49 & 60 & & \\
\hline
\end{tabular}

The TC genotype and $C$ allele were risk factor for DR in type $2 \mathrm{DM}$ patients with OR 3.444 and 1.898 respectively (Table 4). The probability to have complication was $\mathrm{P}=$ OR/(1+OR). The probability of individuals with TC genotype to suffer from DR was $77.49 \%$, while the probability of C allele carriers to suffer from DR was $65.49 \%$.

The influence of TT and TC genotypes of NOS 3 gene toward NO level in type 2 DM was shown in Table 5.
Table 5. The average of NO level between genotypes of T-786C polymorphism in NOS 3 gene in type $2 \mathrm{DM}$ patients

\begin{tabular}{cccc}
\hline \multirow{2}{*}{$\begin{array}{c}\text { type } 2 \\
\text { DM }\end{array}$} & $\begin{array}{c}\text { TT genotype } \\
(\mathrm{n}=60)\end{array}$ & $\begin{array}{c}\text { TC genotype } \\
(\mathrm{n}=20)\end{array}$ & $\begin{array}{c}\mathrm{p} \\
(\mathrm{CI}=95 \%)\end{array}$ \\
\hline $\begin{array}{c}\text { DR and } \\
\text { non DR }\end{array}$ & $7.99 \pm 5.25$ & $1.23 \pm 1.71$ & $0,000^{*}$ \\
\hline
\end{tabular}

The average of NO level in individuals with TT genotype was higher than that in individuals with TC genotype $(7.99 \pm 5.25$ $\mathrm{mg} / \mathrm{dL}$ vs $1.23+1.71 \mathrm{mg} / \mathrm{dL}$ ) and this was statistically different $(p=0.000)$.

The average of NO level between genotypes in DR and without DR type $2 \mathrm{DM}$ was shown in Table 6.

Table 6 . The average type $2 \mathrm{DM}$ of NO level between genotypes in patients with DR and without DR

\begin{tabular}{|c|c|c|c|}
\hline \multirow{2}{*}{ type $2 \mathrm{DM}$} & NO blood lev & (pg/mL) & \multirow{2}{*}{$\begin{array}{c}\mathrm{p} \\
(\mathrm{CI}=95 \%)\end{array}$} \\
\hline & TT genotype & TC genotype & \\
\hline$\overline{\overline{\mathrm{DR}}}$ & $11.27+5.87$ & $1.43 \pm 2.13$ & $0.000^{*}$ \\
\hline non DR & $6.52 \pm 4.32$ & $0.93 \pm 0.65$ & $0.000^{*}$ \\
\hline
\end{tabular}

In type $2 \mathrm{DM}$ patients with $\mathrm{DR}$, the average of NO level in individuals with TC genotype was lower than that in individuals with TT genotype, and this was statistically different $(p=0.000)$. Similar condition was also met in type $2 \mathrm{DM}$ patients without DR.

\section{Discussion}

Genotyping of T-786C polymorphism in NOS 3 gene in this research only found 2 genotypes, TT and TC genotypes. This result was different with the result of Ezzidi et al.(2008) and Awata et al.(2004) That found TT, TC, and CC genotypes. Liew et al.(2009) stated that development of DR was influenced by environmental and genetic factors in population study.

TC genotype and C allele in -786 NOS 3 gene was significant different between type 2 DM with DR and non DR. Individuals with TC genotype had 3.4 time increased risk for DR than individuals with TT genotype, while C allele carriers had 1.9 increased risk for DR. However, Ezzidi et al. (2008) 
reported that there was no statistically significant different of T-786C polymorphism between DR patients and non DR patients in Tunisia $(p=0.069)$. Awata et al.(2004) also reported a similar results as Ezzidi et al.(2008) $(p=0.367)$. The different of ethnic was one of the factors which influence the different in genotype frequency. Moreover, the different of environment in each population influence the development of DR (Liew et al., 2009).

The T-786C polymorphism is located in basal region of NOS 3 gene promoter, that is an active functional element. Ezzidi et al. (2008) reported that allele differences in T-786C polymorphism influence the function and binding activity of nuclear factor that changes transcription level of NOS 3 gene. Decreased expression of NOS 3 gene identified in retinal endothelial cells occur in individuals with CC genotype (Awata et al., 2004). Shear stress stimulates expression of NOS 3 synthesis in endothelial cells, especially the expression of NOS 3 in basal membrane of individuals with TT genotype (Cattaruza et al., 2004). On the other hand, the expression of NOS 3 in individuals with CC genotype did not influence by shear stress. There was variance in the promoter region to interact with transcription factor which stimulated by shear stress. Besides that, the binding between variant in promoter region and transcription factor inhibit protein binding to DNA. In other word, the replication of A1 protein interacted with promoter with $\mathrm{C}$ allele. A1 protein as repressor protein (Miyamoto et al.,2000).

The frequency of TT and TC genotypes of NOS 3 gene between type $2 \mathrm{DM}$ patients with DR and without DR was statistically different $(p=0,011)$. In this study, the Hardyweinberg equlibrium was not fulfilled. Perhaps it was caused by the small number of the studied population, which was not yet enough to fulfilled the equilibrium. Moreover, all of the subjects were type $2 \mathrm{DM}$ patients in Dr. Sardjito Hospital, who were possibly did not represented the population in the community.
This study reported that lower level of NO occurred in individuals with TC genotype than those with TT genotype. Awata et al. (2004) reported the lower of NOS 3 activity in blood of type $2 \mathrm{DM}$ patients with DR than type $2 \mathrm{DM}$ patients without DR. The lower of NOS 3 activity cause the lower level of NO in type $2 \mathrm{DM}$ patients with DR compared to type $2 \mathrm{DM}$ patients without DR.

A low NO level induce the proliferation of smooth muscle of retinal microvascular (Singh et al., 2009). That condition stimulate oxidative stress in retina that lead to change in the structural and functional of retina. Free radical from ROS induced DNA modifications. Reactive Oxygen Species (ROS) increased the vascular permeability and occlusions, decreased of blood flow, disturbed the retinal microvascular barrier, which eventually resulted in retinal neovascularization in DR patient (Cattaruza et al., 2004).

In summary, the T-786C polymorphism in NOS 3 gene was a risk factor for DR in type $2 \mathrm{DM}$ patient. Individuals with TC genotype had lower NO level than TT homozygous individuals. Further study on T-786C polymorphism in NOS 3 gene in different ethnics and its association with other variables, such as blood pressure.

\section{Acknowledgements}

The author would like to thank Dra. Tasmini, M.Kes, dr. Maliyah Madiyan for their help, dr. Haryo Yudono, Sp.M.,M.Sc. and dr.Elly as the advisor of photofundus at Dr. Sardjito Hospital Yogyakarta. The authors would also thank the Head and staffs of Biochemistry Laboratory of Faculty of Medicine Universitas Gadjah Mada; A. Cahyono, Agustina W. Djuma, and Jems K.R.Maay for the assistances. The author also very grateful to all of the type $2 \mathrm{DM}$ patients in Dr. Sardjito Hospital, Yogyakarta who werewilling.

\section{References}

American Diabetes Association. 2010. Standar of Medical Care in Diabetes.Diabetes Care. 31(1), S12-S35. 
Awata, T., Neda, T., Iizuka, H., Kurihara, S., Ohkubo, T., Takata, N., et al. 2004. Endothelial nitric oxide synthase gene is associated with diabetic macular edema in type 2 diabetes. Diabetes Care 27, 2184-2190.

Cattaruza, M., Guzik, T.J., Slowdowski, W. 2004. Shear stress insentivity of endothelial nitric oxide synthase expression as a genetic factor for coronary heart disease. Cir. Res.,95, 841-847.

Departemen Kesehatan R.I. 2008. Laporan Riset Dasar Kesehatan Yogyakarta Tahun 2007. Departemen Kesehatan. Jakarta.

Ezzidi, I., Mtiraoui, N., Mohamed, M.B.H., Mahjoub, T., Kacem, M., Almawi, W.Y. 2008. Endothelial nitric oxide synthase Glu298Asp, 4b/a, and T-786C polymorphisms in type 2 diabetic retinopathy. Clin.Endocrinol., 68, 542546.

Gillies, M.C., Su, T. 1993. High glucose inhibits retinal capillary pericyte contractility in vitro. Ophthalmol., 34, 3396-3401.

Gustaviani, R. 2006. Diagnosis dan Klasifikasi Diabetes Mellitus. Dalam Aru W.S., Bambang S., Idrus A., Marcellus S.K., Siti S.(Eds), Buku Ajar Ilmu Penyakit Dalam, Jakarta : Departemen Ilmu Penyakit Dalam FKUI.

JNC 7. 2003. Seventh Report of Joint National Community on Prevention, Detection, Evaluation, and Treatment of High Blood Pressure American Hearth Association. Inc. Hipertension. 42, 1206-1252.

Liew, G., Klein, R., Wong, T.Y. 2009. The role of genetics in susceptibility to diabetic retinopathy. Opthamol. Clin. 49(2):3552.

Masduki, I., Agni, A.N., Hartono. 2008. Diabetic retinopathy diagnosis with opthalmoscope by trained doctor. Berkala Ilmu Kedokteran. 40(1),26-31.

Mayer, B., Hemmens, B. 1997. Biosynthesis and action of nitric oxide in mammalian cells. Biochem. Jour., 22, 477-481.
Miyamoto, Y. Saito, Y., Nakayama, M. 2000. Replication protein A1 reduce transcription of the eNOS gene containing a-786T $\rightarrow C$ mutation associated with coronary spastic angina. Hum. Mol. Genet., 9, 2629-2637.

Singh, P.P., Mahadi, F., Roy, A., Sharma, P. 2009. Reactive oxyden spesies, reactive nitrogen spesies and antioxidants in etiopathogenesis of diabetes mellitus type 2. Indian J. Biochem., 24(4), 324342.

Supariasa IDN, Bakri B, Fajar I. 2001. Penilaian Status Gizi. Penerbit Buku Kedokteran EGC. Jakarta

WHO. 2006. World Health Organization: definition, diagnosis and classification of diabetes mellitus and its complications: Report of a WHO Consultation. 